\title{
Specific features of special discourse genres in information technology
}

\author{
Anzhela Dolzhikova - Victoria Kurilenko - Yulia Biryukova - Natalia \\ Rumyantseva - Marina Makarova - Ekaterina Kulikova
}

\section{DOI: 10.18355/XL.2017.10.03.01}

\begin{abstract}
The author analyses genres of special discourse related to information technology (IT) in terms of difficulties experienced by translators of scientific and technical texts in understanding them. For this purpose, surveys of professional translators were conducted which made it possible to identify the most typical genres: press release, instruction, corporate website and user's manual. A discourse analysis was carried out of these genres according to specified criteria in order to compare and confirm the results of the survey as well as identify the easiest and the most difficult IT genres for translators to understand.
\end{abstract}

Key words: translation of scientific and technical texts, special discourse genres in IT, press release, instruction, corporate website, user manual

\section{Introduction}

In their professional activities IT translators have to deal with specialized texts of different genres each of which has its own specifics, influencing the understanding and subsequent translation.

Such texts are considered by researchers as a sub-type of the special discourse which is characterised in the context of a certain communication topics and functions, professional status of the information sender and receiver within the framework of a certain social institution, specificity of a communicative situation, and information transfer channel (Gavrilenko, 2010).

Within the special discourse, researchers distinguish its various sub-types: economical, official, scientific, popular-scientific, academic, monographs, textbooks (Gavrilenko, 2010:31; Cuhna, 2007:252; Engberg, 2010:144-152; Gotti, 2004:13). N.N. Gavrilenko distinguishes the discourse sub-types relevant for translators from the viewpoint of the text sender and receiver as well as the information transfer channel. The author refers to them the following sub-types: general scientific, highly specialized and official; and examines them (Gavrilenko, 2010:33-35). Distinguishing these sub-types from the viewpoint of the information sender and receiver seems to be important since this information determines the strategy for the subsequent translation.

However, it should be noted that N.N. Gavrilenko analyses these sub-types taking into account the status roles of specialists whose professional specifics is related to engineering in a general sense, i.e. it differs from an IT engineer's work.

Interviews with graduates of specialized departments at the Moscow Engineering and Physics Institute (MEPhI) and Peoples' Friendship University of Russia (PFUR) have shown that the senders and receivers of the special discourse generally are IT programmers, system administrators, system analysts, etc.

The analysis of the Federal State Educational Standard of higher professional education in the considered sphere and interviews with specialists have shown that programmers create programmes; system administrators provide the operation of software, hardware, local networks, the Internet in their companies; 
system analysts are mainly occupied with analysing data and making decisions on how a system will operate, which methods should be used for the software failure-free operation, and prepare basic technical documents for the customers.

Depending on the situation, the author of the source text creates a certain genre of discourse. For understanding the original text and translating it adequately to the native language, it is important to know the factors of a communicative situation (Gavrilenko, 2010: 90; Iovenko, 1992; Lvovskaya, 2008; Wrede 2016). This makes it necessary to analyse the discourse genres of interest which are found in the translation work.

Researchers have different definitions of the concept of genre. The goals of consideration of the IT genre peculiarities comply with the definition of V.I. Karasik who describes the genre as "the stereotype of generation and perception of speech in specific recurrent circumstances" (Karasik, 2002: 186).

The research analysis and interviews with specialists made it possible to compose a list of typical IT special discourse genres: articles, press releases, monographs, contracts, user guides, corporate websites, computer game translations, user manuals, technical specifications (Pastukhova, Shevchenko, 2002; Porokhov, 2002; Poteryakhina, 2013).

\section{Methodology}

In order to determine the most common genres in the translation work, surveys of Russian and foreign translators were conducted.

\section{Participants}

The survey covered 42 translators: 33 translators working for translation or business companies or on freelance terms in Obninsk, Kaluga, Moscow, Yoshkar-Ola and 9 freelancers working for foreign translation service providers in the Republic of Belarus, France, the Czech Republic, Latvia, Germany, Finland, and the Netherlands).

\section{Data sources and methods for data collection}

The translators were given a list of IT special discourse genres and asked to indicate which ones are encountered in their work rarely, occasionally, frequently, and regularly. The survey made it possible to select the genres, which, in the opinion of the translators, they encounter regularly or frequently. The diagram in Figure 1 shows the IT special discourse genres most frequently encountered by translators.

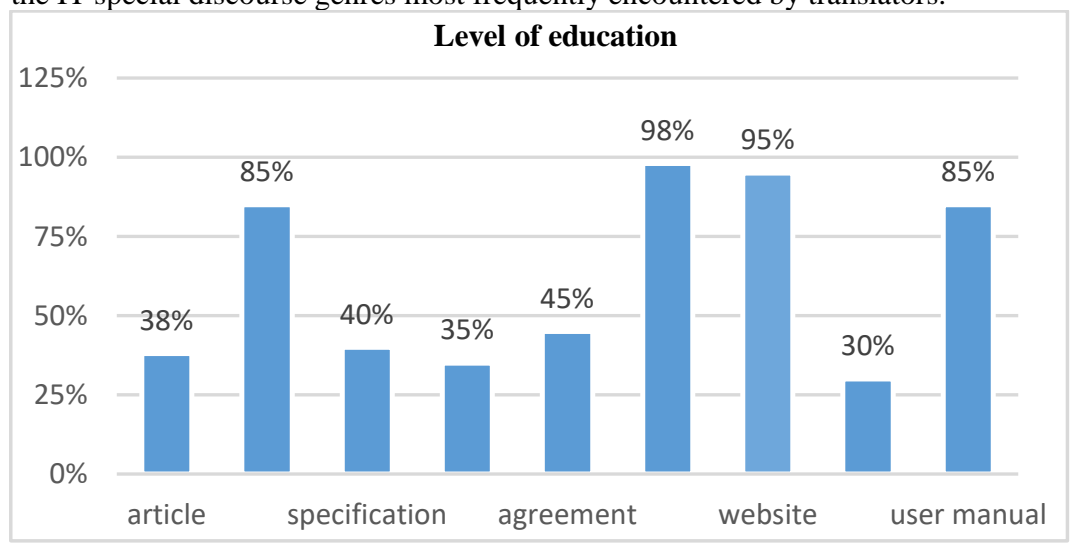

Figure 1: Genres most frequently encountered by translators 
According to the survey results, four of the most common IT special discourse genres in the translation work were selected: instruction, press release, user manual, corporate website.

However, an important problem for translators is also the sequence of IT special discourse genres as the complexity of a perceived text will depend on difficulties it may contain. In order to determine the complexity of these special discourse genres, translators were also asked to place them, depending on the difficulties encountered during reading and understanding, in the order of difficulty. They marked the most difficult genre with the number 4 and the easiest one with the number 1 . The results of this survey are presented in Diagram 2.

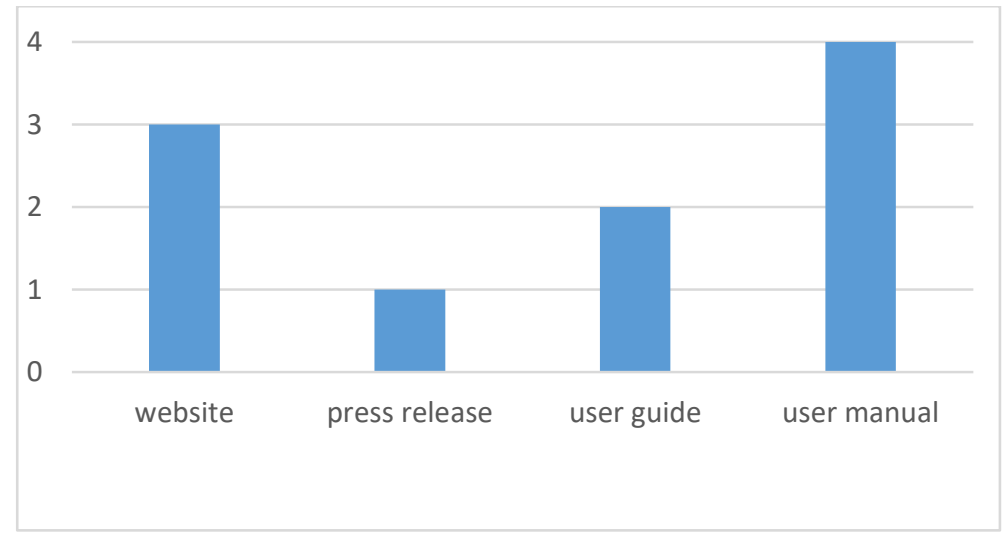

Figure 2: The genres' degree of complexity

According to the results, the most difficult genre comprises user manuals. The least difficulties are experienced by translators while working with press releases. Thus, the genres can be arranged by level of difficulty as follows: press release, instruction, corporate website, user manual.

\section{Analysis of specific features of IT special discourse genres}

In order to compare the results and verify the accuracy of the survey on difficulties encountered by translators while working with the specified genres, 64 texts were analysed (each genre was represented by 16 texts).

A discursive approach to the analysis of texts significantly expanded the range of factors that affect their reading and understanding. Researchers in the field of linguistics consider the following discourse characteristics: (1) author and receiver; (2) communication channel; (3) communication goal; (4) communication pattern; (5) communication type; and (5) discourse volume (Wierzbicka, 1997; Dementyev, 1997; Zemskaya, 1988; Kibrik, 1994; Perez 2015; Makarov, 2003).

Translation theorists, in their turn, suggest to complement the translation analysis with such characteristics as consistency of presentation, external information about a foreign-language text, stylistic and linguistic tools, graphical tools, special utterance duration, genre affiliation, and text informative value (Alekseyeva, 2008; Gavrilenko, 2010; Mirzoyeva L.Yu., Golovshun A. A., 2016; Tsaturova, Kashirina, 2008).

The difficulties associated with understanding the selected genres were analysed based on the translational analysis sequence proposed by N.N. Gavrilenko

XLinguae Journal, Volume 10 Issue 3, June 2017, ISSN 1337-8384 
(Gavrilenko, 2010: 91). Added to this sequence of analysed genres was a factor affecting the translator's reading and understanding of a text, i.e. the specifics of information presented on the computer screen, including:

- communicative function and special discourse goals;

- $\quad$ sender and receiver;

- conditions in which the text was created;

- information transfer channel;

- $\quad$ specifics of information presented on the computer screen;

- $\quad$ special discourse conceptual organisation;

- $\quad$ special discourse linguistic characteristics;

- $\quad$ special discourse duration.

Let us consider in detail the IT special discourse genres in accordance with the complexity estimation given by translating practitioners, ordered by level of difficulty.

The conducted survey showed that the easiest genre in the translation work is press release which is represented as a small message containing news about the organization (person) issuing the press release intended to inform and influence the addressee, creating a favourable image of the addresser.

The author of a press release is a specialist working in a company or organisation and the receiver is the general public. As a rule, press releases on IT topics appear in related print magazines or on Internet websites and belong to general scientific and advertising discourses. A press release is characterised by the presence of emotionally coloured elements as its goal is to convince the readers that the described product is really of good quality and deserves public attention. The presence of emotionally coloured elements in the press release genre complicates its reading and understanding for the purpose of a subsequent translation (Gavrilenko, 2010; MinyarBeloryuchev 2010, Troyanskaya, 1989). Also, in press release texts, IT-related terms may be used which should be correctly read and understood by the translator in order to make a subsequent translation. Translating terms, according to the researchers, may cause difficulties in understanding and subsequent translation of the text (Gavrilenko 2010; Trojan 1989, Hervey, Higgings 2002: 173).

The volume of a press release, as a rule, does not exceed two printed A4 sheets.

A typical press release structure includes, as noted by researchers, a headline, a lead paragraph, a body, and a boilerplate (Busygina, 2010; Pastukhova, Shevchenko, 2002; Porokhov, 2002). IT-related press releases issued have a similar structure. The method of narration implies deduction which is characterised by consistency and clarity of presentation. The purpose of a press release is formulated at the beginning, i.e. in the lead paragraph.

The texts of press releases may contain abbreviations to be deciphered in brackets, and loanwords from different languages.

Given below is an example of abbreviations and terms in a press release on the latest technologies used in smart-phones posted on the Samsung official website:

Figure 3: www.samsung.com

With a mere package size of $2.4 \mathrm{~mm} \times 2$.4mm, the industry's smallest for stand-alone NFC IC's, the new NFC IC offers mobile device designers a more flexible and efficient printed circuit board (PCB) layout. For smartphone manufacturers, the chip's pin-to-pin compatibility also allows convenient application as a stand-alone NFC IC or NFC System-in-Package (SiP) with embedded secure element (eSE). 
Press releases on the Internet sites may contain links to additional information in the form of hypertext which is a "sign design (text in a broad sense) with a multi-format information presentation (combining text, graphics, video, and audio) in electronic form where the mechanism of hyperlinks makes it possible to connect elements (information units)" (Ilyina, 2009: 24). As a rule, these elements are logically unconnected, which may cause difficulties in translating scientific texts (Gavrilenko, 2010; Porshneva, Abdulmianova 2015; Ustinova, Polyakova, 1990). It should also be noted that there may be numerous hyperlinks, and their presence may hinder, as noted by N.N. Gavrilenko, understanding and translating (Gavrilenko, 2010).

Thus, when dealing with a press release, the translator may face difficulties such as emotionally coloured elements, presence of terms and abbreviations, absence of a logical link in the case of hyperlinks in the original text, and a large volume due to their unlimited quantity.

The next genre pointed out by the translators during the survey is instruction, the main goal of which is to inform the user about possible operations with the product (Alekseyeva, 2008: 177).

An instruction presents to the user a coherent description of each operation performed with respect to a programme or technical device to ensure their proper use.

As a rule, the author of instructions is a technical writer, a programmer, or a systems analyst, narrowly specialized in the IT sphere, working on behalf of the company, who has relevant experience in writing such documents and is familiar with the presented product.

The receiver is a consumer of the product who should become familiar with the operation of the programme or technical device. Instructions can be transferred via email.

The language of instructions should be very clear to the users who may not have special technical education. This genre can be referred to the general scientific subtype of the special discourse.

The texts of instructions usually bear no author's signature but the manufacturing company responsible for the presented information is always mentioned. Instructions are clearly regulated by State Standard (GOST) on the territory of the Russian Federation and the Joint Technical Committee abroad. An analysis of instructions has shown that they may contain such headings as general guidelines, body, safety requirements, warranty, etc.

Almost every operation described in the instructions is accompanied by a diagram, photo or screenshot to clarify and facilitate the process of familiarization with the programme or technical device.

The headings of instructions can be interconnected by a system of links so as to redirect the translator to the desired section and thus facilitate the translation work and save the operating time.

Instructions are usually small in volume; all information is presented in a compressed, concise form. The average length of sentences is about 16 words.

The method of presentation in the instructions to hardware and software is deductive. First the paragraph content is described and then the basic information is presented.

Instructions often contain new terms which can complicate their reading and further translation (Gavrilenko, 2010; Troyanskaya 1989; Hervey, Higgings, 2002: 173). Nonverbal information, e.g. drawings without decoding can cause additional difficulties in reading, understanding and translating this special discourse sub-type (Gavrilenko 2010; Klimzo 2011). As long as, currently, a translator deals mostly with electronic version of texts, for more clarity and visual similarity between instructions in the target and source languages, figures and schemes contained in the target language can be copied and inserted into the target text with a translation. Note that at the stage of reading, a 
translator identifies information to be further adapted to the cultural characteristics and mentality of the receiver.

The use of terms and concise expressions as well as the composition of genres introduce clarity and precision into instructions, eliminate emotionality and render informational intensity that could complicate reading, understanding and translation of this genre (Gavrilenko, 2010).

Thus, high information intensity including drawings, schemes and figures containing non-verbal information, terms without explanations as well as the need to adapt the text to cultural characteristics and mentality of the targeted audience may complicate the translator's reading of this genre.

Currently, it is becoming common practice for translators to deal with such a genre as corporate website, i.e. a web resource presenting on the Internet the business performance of a company, enterprise, bank or corporation (Ovchinnikov, Sukhov; 2009: 30).

A properly translated corporate website is an effective way to draw attention to the company's products in a new market.

The author of an IT corporate website is usually a team of experts: company management, editors, persons responsible for text generation, programmers, system administrators, system analysts, and others.

A corporate website is aimed at a certain group of users interested in information products for their specific purposes. They can be potential or current customers, business partners, media, competitors in the same professional field, job seekers, or the company's own employees.

Thus, the targeted audience of a corporate website is quite extensive and diverse. But common for all the addresses is the fact that they visit the site in order to obtain some information on the subject before acquiring some IT products or services, making agreements on cooperation with new business partners, obtaining vacant positions, etc. A corporate website is in fact an advertising space which makes it possible to most efficiently provide the potential customers with information about the proposed IT products and services. This genre can be included with the advertising sub-type of the special discourse.

The structure of a corporate website suggests a number of sections, each of which is to solve any particular problem for the addressee and characterize the company performance. Thus, an analysis of various corporate sites has revealed a typical structure including such sections as: general information on the company; news; products and services; questions/responses; banners; gallery; forum; chat; contacts, vacancies, site search, etc.

Each section is a separate page with a specific location; the method of presentation is deductive: the structure includes a header, an introduction, a body and a conclusion. But, as a rule, logics and links are absent due to a large amount of hypertext in each section. The absence of a logical connection will complicates translation of a certain scientific or technical text (Gavrilenko, 2010; Ustinova, Polyakova, 1990). The translation work with this genre will also be complicated due to the increased number of hyperlinks which may redirect the translator to other sites (Gavrilenko, 2010).

Researchers also note that the text location on a website has its own peculiarities. For example, a text on the Internet can be arranged without indenting paragraphs. Single ideas are separated by blocks or remain unseparated. These peculiarities complicate the process of reading (Dillon, 1992).

While dealing with the "corporate website" genre, a translator should take into account the fact that this special discourse sub-type in the source language is aimed at addressees speaking this language and holding to their own country's historical, cultural, social and economical traditions. Translators should be familiar with foreign language features and be able to adapt (or localise) a corporate website content to the cultural patterns and mentality of the targeted audience. Website localisation, according to the translators-participants of the survey, makes it difficult to read and understand texts. 
The difficulty in reading a corporate website, as noted by researchers, may be due to emotionally coloured elements (Gavrilenko, 2010; Troyanskaya, 1989), non-verbal information in the form of images (Gavrilenko, 2010), and precision words (Gavrilenko, 2010; Troyanskaya, 1989).

Sentences in the "corporate website" genre are simple; their average length is about 21 words.

Therefore, translation of texts of this genre can be complicated due to emotionally coloured elements; non-verbal information; precision words; hypertexts; absence of logical links between the parts of a text; adaptation (or localisation) of a website text; large volume due to numerous hyperlinks; specific text location on the website page.

Another special discourse genre is user manual.

A user manual contains a complete consecutive description of a programme or technical device, which is necessary for their use. The targeted audience of user manuals are qualified specialists, including IT department managers who receive these documents via e-mail for consideration or system administrators and analysts who use various programmes or technical devices to solve their professional tasks. The author is usually a technical writer employed by a company, experienced in writing such documents and familiar with the presented products.

The structure and content of product user manuals distributed in the Russian Federation are subject to the rules and regulations reflected in the State Standard (GOST) which is a regulatory document establishing a set of rules, regulations and requirements for the subject of standardisation (Ivannikov, Fomichev, 2001; Rebrin, 2004; Yakushev, 1987).

IT standards are developed by the Joint Technical Committee. The main task of the Committee is to develop basic IT standards irrespective of their application area in order to improve the quality and technical level of designed information telecommunication systems as well as the performance and quality of programmers' work; simplify the process of IT introduction into various spheres of human activity; and enhance public safety, health and well-being.

In reading user manuals, translators should pay attention to the normative base indicated in them and decide whether to adapt (localise) these norms according to the RF standards or make a translation taking into account the standard specified in the source language, with reference to it. As the survey of translators showed, adaptation (localization) can present additional difficulties for a translator in reading a user manual.

The "user manual" genre is an example of the special discourse with official discourse elements since, for the one hand, it is aimed at IT-focused specialists but, on the other hand, it is an official document of the presented product which may be addressed to the company management intending to use it.

The analysis showed that user manuals have structural elements of different levels: sections, subsections, paragraphs, subparagraphs, etc. These elements may not be logically linked with each other which, as noted by researchers, may hinder the process of reading, understanding and subsequent translation (Gavrilenko, 2010; Ustinova, Polyakova, 1990). A header should be assigned to each structural element. The composition of sections and their sequence order is usually determined by the type of the document and can be taken from the applicable standard. The number of sections in the document is not limited.

A user manual in the form of a single document may include a system of links to redirect a reader to other pieces of information contained therein. For example, a click with a left mouse button on the "Content" section will redirect a reader to the selected section, subsection, paragraph or subparagraph. This feature facilitates the work of translators and saves their time in finding the necessary structural element. 
The average length of sentences in a user manual is about 26 words, which hinders understanding of the text and its subsequent translation (Gavrilenko, 2010; Chall, 1988; Li, Carpuat, Nenkova, 2014).

The user manual vocabulary is strictly constrained by the framework of the problem to be solved. Note the large number of terms which may complicate the further translation (Gavrilenko 2010; Troyanskaya, 1989; Hervey, Higgings 2002: 173). As an example, let us consider the GNU program user manual which contains a large number of terms:

\begin{abstract}
You can make your jpegs smaller without changing the pixel width of the image. Actually you can change the weight of the image a lot. I used an(other) image from APOD [APOD04]. The original image is huge (3000 pixels wide) so I also made a smaller (pixel width) image available. To prepare this image for the web, you should first reduce the image to a better width and height for web viewing as described in the Section 3.4.2. Right click on the properly scaled image and follow the menus File $\rightarrow$ Save As... at the image window. The Save Dialog will pop up.
\end{abstract}

\title{
Figure 4: GNU Image Manipulation Program
}

It should be noted that the terminology related to the subject area should be uniform; otherwise, it can cause more difficulties in reading and subsequent translating (Gavrilenko, 2010). But, in this case, it should always be kept in mind that translations of this genre are made by a team of translators who are provided with a common termbase and relevant customer requirements.

In this genre, direct and concrete indications to the objects and functions are used; frequent are sentences in the imperative mood. Definitions in a user manual are strict, concise, unambiguous, without vague descriptions or unnecessary words, not allowing multivalent interpretations.

There may also appear abbreviations accepted by the authors which, as noted by researchers, may complicate the translation (Gavrilenko, 2010; Troyanskaya, 1989). They are usually presented at the beginning of a user manual, in a separate section, i.e. the glossary.

The deductive method of presentation dominates in this genre; it is characterized by consistency and clarity.

There is no emotional colouring. This is an information-intensive genre; however, this information intensity may cause difficulties in the translation (Gavrilenko, 2010).

Thus, when working with texts of the "user manual" genre, translators may undergo difficulties due to the extensive system of logically unconnected sub-topics; volume; informative intensity; numerous new terms and their non-uniform usage in the whole text; abbreviations which may remain deciphered in a manual; and adaptation (or localisation).

\section{Results and discussion}

To calculate the overall difficulty of each genre, the difficulties discussed during the analysis of the most common IT special discourse genres were assumed to be equal to 1 ; the general level of difficulties was determined by adding them up.

Figure 5 shows the obtained results. 


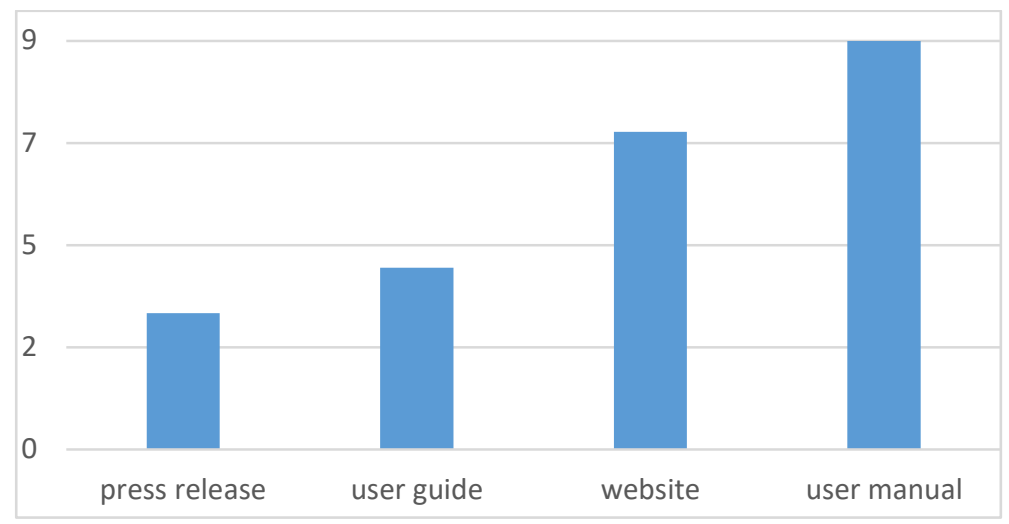

Figure 5: Difficulty level of IT special discourse genres

These findings coincide with the data obtained in the survey of translators; thus, it is possible to arrange the IT special discourse genres in order of difficulty: press release, instruction, corporate website, user's manual.

\section{Conclusions}

Consideration of the IT special discourse genres is important in terms of the complexity of their understanding by translators.

The survey of professional translators made it possible to identify the most common genres encountered by the translators of scientific and technical texts: press release, instruction, corporate website, and user manual.

These genres were analyzed for the difficulties encountered by the translators in their work with the selected special discourse genres; 64 texts were analyzed (each genre was represented by 16 texts) in order to compare the results and verify the accuracy of the survey as well as identify the easiest and the most difficult genres.

The obtained data were consistent with the results of the survey among the translators; they made it possible to identify the easiest and the most difficult genres for a translator's understanding.

The results of the survey of the professional translators and the analysis of the IT special discourse genres may be used by linguists for considerations of different discourse genres.

This information may also be useful for familiarisation of future IT translators with the special discourse genres most commonly encountered in this area.

\section{Bibliographic references}

ALEKSEYEVA, I.S. 2008. Professionalniy trening perevodchika [Professional translator training]. St. Petersburg. 288 p. ISBN: 5-94033-040-1.

CUNHA, I. - WANNER, L. - CABRÉ, L. 2007. Summarization of specialized discourse: The case of medical articles in Spanish. In: Terminology, vol. 13, no. 2. pp. 249-286 ISSN 0929-9971.

DEMENTYEV, V.V. 1997. Study of speech genres: a review of works in contemporary Russian studies. In: Voprosy yazykoznaniya [Problems of Linguistics], no 1, pp. 109-121. ISSN 0373-658X (in Russian).

DILLON, A. 1992. Reading from paper versus screens: a critical review of the empirical literature. In: Ergonomics, no. 35 (10), pp. 1297-1326. ISSN 1460-2067. 
ENGBERG, J. 2010. Languages for Specific Purposes. Concise encyclopedia of applied linguistics. Oxford: first edition. 592 p. ISBN 9789382291312.

GAVRILENKO, N.N. 2010. Ponyat, chtoby perevesti: perevod $v$ sfere professionalnoy kommunikatsii [To understand in order to translate: professional translation for expert communities]. Book 2 Moscow: Scientific-Technical Society named after Academician S.I.Vavilov. 206 p. ISSN 2071-825X.

GNU Image Manipulation Program. 2007. User Manual [online] URL: https://docs.gimp.org/2.4/pdf/en.pdf .

GOTTI, M . Specialised Discourse in Multilingual and Multicultural Contexts. pp. 520 [online] URL: http://asp.revues.org/839 ISBN 978-3034306706.

HERVEY, S. - HIGGINS, I. 2002. Thinking French Translation. A Course in Translation Method: French to English. London: Routledge. 287 p. ISBN 10: 0415255228.

ILYINA, O.K. 2009. Using the case method in the practice of English language teaching. In: Country Studies Through Language: analysis methods, educational technology: $6^{\text {th }}$ Interuniversity Seminar on Country Studies Through Language. Language in the aspects of country studies through language: coll. of scient. articles: in 2 parts, Part 1. Moscow: MSIIR University. pp. 253-261._ISBN 978-5-209-025689 (in Russian).

IOVENKO, V.A. 2005. Teoreticheskiy kurs perevoda. Ispanskiy yazyk [Theoretical course of translation. Spanish]: textbook. Moscow: CheRo Publ. 132 p. ISBN 588711-169-0.

IVANNIKOV, D.A. - FOMOCHEV, YE.N. 2001. Osnovy metrologii i organizatsii metrologicheskogo kontrolya [Fundamentals of metrology and organization of metrological control]. Nizhniy Novgorod: NNSTU. 116 p. ISBN 5-7695-2058-2.

KIBRIK, A.A. 1994. Cognitive studies of discourse. In: Voprosy yazykoznaniya [Problems of Linguistics], no. 5, pp. 126-139. ISSN 0304-3487 (in Russian).

KLIMZO, B.N. 2003. Remeslo tekhnicheskogo perevodchika: Ob angliyskom yazyke, perevode i perevodchikakh nauchno-tekhnicheskoy literatury [Technical translator's craft: on the English language, translation and translators of scientific and technical literature]. Moscow: R. Valent Publ. 288 p. ISBN 978-5-93439-314-5.

LI, J.J. - CARPUAT, M. - NENKOVA, A. 2014. Cross-lingual Discourse Relation Analysis:A corpus study and a semi-supervised classification system. [online]. URL: www.aclweb.org/anthology/C14-1055 (accessed data: 05/14/14). ISBN 978-1941643-26-6.

LVOVSKAYA, Z.D. 2008. Sovremennye problemy perevoda [Modern problems of translation]. Moscow: LKI Publ. 224 p. ISBN 978-5-382-00125-8.

MAKAROV, M.L. 2003. Osnovy teorii diskursa [Fundamentals of discourse theory]. Moscow: Gnozis Publ. 280 p. ISBN 5-94244-005-0.

MIRZOYEVA L.YU. - GOLOVSHUN A. A. 2016. Cognitive procedures as an instrument of translation process analysis. In: XLinguae. European Scientific Language Journal. Volume 9, Issue 4. pp. 9-24. ISSN 1337-8384.

MINYAR-BELORUCHEV, R.K. 2000. Kak stat perevodchikom? [How to become a translator?] Moscow: Gotika Publ. 176 p. ISBN 5-7834-0035-1.

OVCHINNIKOV, R. - SUKHOV, S. 2009. Korporativniy website na $100 \%$. Trebuyte ot sayta bolshego! [A 100\% corporate site. Demand from the site more!] St. Petersburg: Piter Publ. 320 p. ISBN 978-5-49807-173-2.

PASTUKHOVA, M.V. - SHEVCHENKO, E.V. How to make and send a press release to the media. [online]. URL: http://www.good.cnt.ru/p7_53.htm (accessed date: $10 / 10 / 14)$.

PEREZ, E. 2015. Translation and Subtitling of Documentary Films in Teaching Foreign Languages and Intercultural Communication. In: XLinguae. European Scientific Language Journal. Volume 8, Issue 1. pp. 28-35. ISSN 1337-8384. 
PORSHNEVA, E. -ABDULMIANOVA I. 2015. Assessing the Maturity of General Professional Competencies of Future Interpreters/ Translators: Problems and Solutions. In: XLinguae. European Scientific Language Journal. Volume 8, Issue 4. pp. 60-65. ISSN 1337-8384.

POTERYAKHINA, I.N. 2013. Genre-generating elements of a corporate site. In: Vestnik Chelyabinskogo gosudarstvennogo universiteta [Bulletin of the Chelyabinsk State University], no. 37 (328), pp. 49-51. ISSN 1997-9886.

PROKHOROV, S.YU. 2002. A trap for a journalist. In: Industriya reklamy [Advertising Industry], no. 15, pp. 28-30. ISSN 1681-7494.

REBRIN, YU.I. 2004. Upravleniye kachestvom [Quality Management]. Taganrog: TGTU Publ. 174 p. ISBN 5-8327-0177-1.

SHVEITSER, A.D. 1988. Teoriya perevoda: status, problemy, aspekty [Theory of translation: status, problems, aspects]. Moscow: Nauka Publ. 216 p. ISBN 5-02010882-0.

TROYANSKAYA, E.S. 1989. Obucheniye chteniyu nauchnoy literatury [Learning to read scientific literature]. Moscow: Nauka Publ. 272 p. ISBN 5-02-010940-1.

TSATUROVA, I.A. - KASHIRINA, H.A. 2008. Perevodcheskiy analiz teksta. Angliyskiy yazyk [Translational analysis of text. English ]. $2^{\text {nd }}$ edition, corrected and complemented. St. Petersburg: Perspektiva; Soyuz Publ. 296 p. ISBN 978-5-91413-016-6.

USTINOVA, I.P. - POLYAKOVA, M.S. 1990. Saving the pragmatic aspects of scientific and technical texts in translation. In: Problems of theory and practice of translation of scientific and technical literature. Penza. pp. 33-34. ISSN1997-2911(in Russian).

WIERZBICKA, A. 1997. Speech genres. In: Zhanry rechi [Genres of speech]. Saratov: "Kolledzh" Publ. pp. 99-111. ISSN 2311-0740 (in Russian).

WREDE, O. 2016. Legal Text in Terms of Didactics in Specialized Translation. In: XLinguae. European Scientific Language Journal. Volume 9, Issue 1. pp. 59-82. ISSN 1337-8384.

YAKUSHEV, A.I. - VORONTSOV, L.M. - FEDOTOV, N.M. 1987. Vzaimozamenyayemost, standartizatsiya $i$ tekhnicheskiye izmereniya [Interchangeability, standardization and technical measurements]. $6^{\text {th }}$ edition, corrected and complemented. Moscow: Mashinostroyeniye Publ. 352 p. ISBN 594227-014-7.

ZEMSKAYA, E.A. 1988. Urban spoken language and objectives of its study. In: Raznovidnosti gorodskoy ustnoy rechi [Varieties of Urban Spoken Language]. Moscow. pp. 5-43. ISSN 0304-3487 (in Russian).

Words: 4798

Characters: 28468 (15,8 standard pages)

Prof. Anzhela Dolzhikova, PhD

Vice Rector

RUDN University

Miklukho-Maklaya street, 6

117198 Moscow Russia

pfurteachers@gmail.com

Prof., Victoria Kurilenko, $\mathrm{PhD}$

Head of Russian language department

Medical Institute

RUDN University,

Miklukho-Maklaya street, 6

XLinguae Journal, Volume 10 Issue 3, June 2017, ISSN 1337-8384 
117198 Moscow Russia

vbkurilenko@gmail.com

Assoc. Prof., Yulia Biryukova, PhD

Russian language department

Medical Institute

RUDN University,

Miklukho-Maklaya street, 6

117198 Moscow Russia

yu.birukova@gmail.com

Professor, Natalia Rumyantseva, $\mathrm{PhD}$

Russian Language Department

Russian Language and Basic Sciences Faculty

RUDN University,

Miklukho-Maklaya street, 6

117198 Moscow Russia

authorsrudn@gmail.com

Assoc. Prof., Marina Makarova

Russian language department

Medical Institute

RUDN University,

Miklukho-Maklaya street, 6

117198 Moscow Russia

authorsrudn@gmail.com

Assoc. Prof., Ekaterina Kulikova, PhD

Head of Language Teaching and Testing of Migrants Centre

RUDN University,

Miklukho-Maklaya street, 6

117198 Moscow Russia

authorsrudn@gmail.com 